\title{
‘Ain't I a Woman?' Grace Nichols and M. NourbeSe Philip. Re-Membering and Healing the Black Female Body
}

\section{Myriam Moïse}

\section{OpenEdition}

\section{Journals}

Electronic version

URL: http://journals.openedition.org/ces/303

DOI: $10.4000 /$ ces.303

ISSN: 2534-6695

Publisher

SEPC (Société d'études des pays du Commonwealth)

\section{Printed version}

Date of publication: 1 April 2018

Number of pages: 135-147

ISSN: 2270-0633

\section{Electronic reference}

Myriam Moïse, "'Ain't I a Woman?' Grace Nichols and M. NourbeSe Philip. Re-Membering and Healing the Black Female Body", Commonwealth Essays and Studies [Online], 40.2 | 2018, Online since 05 November 2019, connection on 03 April 2021. URL: http://journals.openedition.org/ces/303 ; DOI: https://doi.org/10.4000/ces.303

\section{(c) $($ i) $(9)$}

Commonwealth Essays and Studies is licensed under a Licence Creative Commons Attribution - Pas d'Utilisation Commerciale - Pas de Modification 4.0 International. 


\section{'Ain't I a Woman?' \\ Grace Nichols and M. NourbeSe Philip Re-Membering and Healing the Black Female Body}

The black African body is a highly historicised space as it has been tortured and traumatised through the processes of enslavement and colonialism. As for the black female body,

a raced and gendered space, it has been even more exploited, objectified and fragmented by hegemonic and patriarchal systems. In diasporic Caribbean women's literature, the black female body is often depicted as a site of tension, and a complex entity struggling to make itself heard outside of historical spaces of oppression and mutilation. This body needs to transcend traumatic memory in order to renew and heal. Grace Nichols's The Fat Black. Woman's Poems and M. NourbeSe Philip's She Tries Her Tongue, Her Silence Softly Breaks and A Genealogy of Resistance allow the black female body to be heard beyond intersectional oppressions. This paper seeks to demonstrate how these women writers embody resistance as they assert corporeal visibility and allow transcultural bodies to speak and heal through creative discourse.

\section{Look at me! Look at my arm! I have ploughed and planted and gathered into barns, and no man could head me! And ain't I a woman?}

(Truth 253)

Black female abolitionist Sojourner Truth's question "Ain't I a woman?" in her wellknown 1851 speech at the Ohio Women's Suffrage convention emphasises the need for the woman of African descent to assert her womanhood through the reconstruction and liberation of her body and tongue. Truth urges her audience to look at her and attracts attention to the very characteristics of a black female body, which is marked by gender as well as race and class. She overtly challenges the construction of popular stereotypical representations of the black female as voiceless and passive and asserts her physical presence, thus reclaiming her female body and her humanity. It is indeed her incorporeal body that Truth reasserts on stage as in traditional African cosmology, the human body is perceived as "a capsule, an integral whole, incorporating blood, water, fire, air, soil, and all other symbols of life" (Wainwright and Tucker 680). Contrastingly, in the Eurocentric Christian-based and Puritan-influenced systems of thought, the body is mostly perceived in physical terms, as it is seen as a purely biological object. According to Western philosophy, the body is a fixed entity and an object which is controlled by the power of the mind.

Feeling restricted by this body/mind dichotomy and the imperfect bodily identity that patriarchal discourses granted them, numerous European feminist theorists contrived to resist the fixedness of these conceptual frameworks and rethink the female body. A number of European egalitarian feminists such as Mary Wollstonecraft ${ }^{1}$ and Simone de Beauvoir have attempted to redefine womanhood taking into account the specificities of the female body through its capacities for reproduction. While de Beauvoir's question "What is a woman?" is fundamentally linked to the restrictive vision of the

1. See Wollstonecraft's A Vindication of the Rights of Woman, 1833. 
female body as the exclusive marker of womanhood, in her 1949 pioneering work The Second Sex, she opens the debate on the cultural "constructedness" of femininity, claiming that the woman is not born, but made. De Beauvoir's distinction between sex (as purely biological) and gender (as socially and discursively constructed) has actually paved the way for most contemporary feminists such as Nancy Chodorow, who have valued the notion of subjectivity as socially constructed. ${ }^{2}$ Constructionist feminists have indeed focussed on cultural values and meanings, and have not considered biological differences as central. In a sense however, these constructionist theories reiterate patriarchal binaries between body and mind, as Elizabeth Grosz argues that according to them, "the body itself, in the strongest version of this position, is irrelevant to political transformation, and in the weakest version is merely a vehicle for psychological change" (Volatile Bodies 17). Indeed, through their dismissal of the body as subjective, constructionists have failed to consider the female body within its lived experience and its incorporated specificities in terms of race, class and gender. In other words, European feminists "have often assumed a universal body, an assumption that has usually left some women silenced, inhabiting the borderlands" (Conboy, Medina and Stanbury 3).

It is clear however that the female body cannot be universalised nor can it be "understood as an ahistorical, biologically given, acultural object" (Grosz, Volatile Bodies 18). The concern of this study being the African Caribbean female body, the theories of feminists such as Gayatri Spivak or Luce Irigaray, who consider the raced, gendered and classed bodies through the notion of the "lived body" appear as the most relevant. As Spivak puts it, "if one thinks of the body as such, there is no possible outline of the body as such. There are thinkings of the systematicity of the body, there are value codings of the body. The body, as such, cannot be thought" ("In a Word" 127). The body is therefore a product of the tensions between women's lived experiences and the cultural meanings which have marked women's bodily experiences. As a matter of fact, the black female body must be analysed within its very specificities, as a marked historicised space of conflicts, a site of trauma and dehumanization through the processes of enslavement, colonialism and neo-colonialism.

The bodies of enslaved African women have been cruelly exploited, sexually abused, chained, pried open, flayed and discarded, and were exposed to the same severe working conditions as their male counterparts that they often outnumbered as field hands. As significantly pointed out in the introduction to Recovering the Black Female Body: Self Representations by African American Women,

In slavery, the black female body served as one of the prime technologies of reproduction and commodification. [...] In short, historically and socially, the black female body tends to be defined and viewed as the antithesis of the good, the true, and the beautiful. Demonized, debased, raped, dismissed - no other body in the United States has been so materially and discursively hobbled. (Bennett and Dickerson 13)

Bennett and Dickerson's scholarly volume is relevant to this study as it explores the extent to which African American women have developed discursive strategies to reclaim their own bodies; "how they have deployed and redeployed language and signs to revise and repossess the discursive body and how the material body has been recovered through performance and other transformative and transgressive acts" (13). Whether

2. See Nancy Chodorow's influential book The Reproduction of Mothering, 1978. 
it took place in the cotton fields in the Southern United States or on the sugar cane plantations in the Caribbean, the African woman's experience of enslavement has been one of resistance against all forms of oppression and one of bodily and discursive reclamation and self-reconstruction. As theorised by feminists Gayatri Spivak, Luce Irigaray and Hélène Cixous through their concept of "écriture feminine" or "writing the feminine body,"

The only way to move from a position of objectified servitude to a position of full subjectivity is for women to write the truth of their bodies. Thus, the cry to produce embodied, personal, deeply felt "feminine" writing, in one's true voice, serves as a call for independence. (Senft 276)

The voice is essentially embodied: feminine writing embraces the liberation of body and voice, and in the case of women of African descent, memory and re-membering play a key part in this process. This paper examines a selection of poetic excerpts by Trinidadian Canadian writer NourbeSe Philip and Guyanese British poet Grace Nichols, so as to get an insight into their strategies for imposing a re-writing/righting of their bodies, for reclaiming their tongues and reconstructing their subjectivities. I wish to demonstrate the extent to which these two diasporic African Caribbean writers allow the body "to erupt" into their texts as Philip would put it. Philip and Nichols develop two rather unconventional approaches to the black female body: the first draws on the synecdoche of the tongue and the incrimination of English as the language of the oppressor, while the second sublimes the fat black woman's body, thus rejecting Western norms of beauty. The question is, to what degree do they manage to make the diasporic African Caribbean female body visible, audible and tangible, hence reconstructing and re-membering it beyond historical trauma?

To NourbeSe Philip, the re-acquisition of power essentially resides in the capacity to recreate one's own "I-mage," a fundamental process to achieve self-assertion:

The power and threat of the artist, poet or writer lies in this ability to create new I-mages, I-mages that speak to the essential being of the people among whom and for whom the artist creates. If allowed free expression, these I-mages succeed in altering the way a society perceives itself and, eventually its collective consciousness. (She Tries Her Tongue 78)

As Curdella Forbes explains in her study "This Space/Dis/Place Between: The Poetics and Philosophy of Body, Voice and Silence," "the act of I-maging incorporates the history of rapine and degradation into the being that comes to voice; equally, it does violence to English language in order to realize its own resistive, transformative power" (80). The notion of I-mage therefore entails a genuine process of self-definition and selfreconstruction through the discursive self. As voice and trauma are embodied, the black female body is a body-memory, one that expresses the interconnection between time, self and voice, a dialectic that may allow self-recovery. As Deleuze argues, "memory is the real name of the relation to oneself, or the affect of self by self":

Time becomes a subject because it is the folding of the outside and, as such, forces every present into forgetting, but preserves the whole of the past within memory: forgetting is the impossibility of return and memory is the necessity of renewal. (89)

Philip's texts She Tries Her Tongue, Her Silence Softly Breaks (1989) and A Genealogy of Resistance (1997), and Grace Nichols's The Fat Black Woman's Poem offer comparable prospects of bodily re-membering and processes of healing and renewal. In her prose and poetry 
work A Genealogy of Resistance, Philip denounces the dislocation of African Caribbean female bodies and depicts bodies in search of discursive recreation, provided that the black African women's tongues be re-membered.

In the New World, the African woman creating life and seeing the men - the white men - taking away her children and selling them. The man who walking, getting into his boat, his plane, his ship, taking the product of her body and the body's wisdoms - her children - like he taking the crops she tending. Body and Place. Fertilized. Cultivated. Harvested. In the same way. Between parent. And child. Mother. And child. Father. And child. (93)

This excerpt denounces the black female's objectification in the process of enslavement, which took "the product of her body and the body's wisdoms." Body and place appear as intrinsically linked through the predominance of the semantic field of cultivation. The black female body is dehumanised and metaphoricised as land, as it is ploughed, fertilized and harvested for reproduction. Philip indeed appears to engage in a sort of "body-land-language association," the body being "a metaphoric construct, still marked by the gender/power association, which can apply to architecture, the state, language, or any other structure - including land" (New 110). Echoing Ben Heller's statement in "Landscape, Femininity and Caribbean Discourse" that Caribbean landscapes are often metaphoricised as feminine, the black female body is here depicted as colonised and abused in the same way as the land. In Philip's Genealogy, the repeated use of passive structures and the ruptured structures evoke the dislocation and fragmentation of families, as enslaved mothers were deprived of their children. Through the ellipsis of the auxiliary verbs, which is typical of the Caribbean Creole demotic, criminal processes are condemned in a more straightforward manner and enslavers are openly accused of depriving African women of their bodies, and of their very being. Far from performing victimhood, the following verses brutally highlight some of the rebellious responses from African women to the dispossession of their bodies:

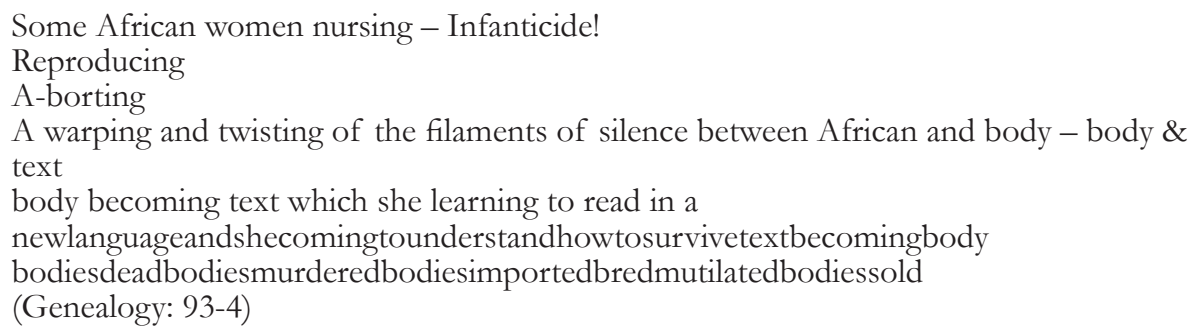

Recalling the horrible facts, Philip engages her reader in an exploration of the black female body as profoundly mutilated and fractured, but also as intrinsically associated with the text. From "body and place" in the earlier verses, this stanza now pictures "body \& text," "body becoming text," thus the survival of the body resides in its very capacity to become tongue in order to voice its trauma and recreate itself discursively. The absence of punctuation and the opacity of the last section convey a suffocating feeling that may force the reader to imagine this dismembered body scarred by rejected maternities and striving for survival. While the African Caribbean female has long been depicted as a silent victim, Philip here underlines her silence as a tool for resistance and reparation through acts of rebellion such as abortions and infanticides, which were used as forms of bodily resistance against patriarchal oppressions. Resistance and selfreliance therefore allow the black female subject to assert her self-power and construct 
a new language which is translated in the final series of lines with connected words. The absence of spaces between the words further conveys the intimate connection between body and text. Despite the distortion and murder of physical/material bodies, new discursive bodies are created as the textual bodies transcend trauma and assert their unalterable presence on the page. In order to resist oppression, the enslaved woman vows to control her fertility and her children's fate, thus repossessing her rights to her body and mind, a recurrent pattern in slave narratives.

Bodily reconstruction through discourse is in fact a common pattern in slave narratives by women. In The History of Mary Prince, the only published narrative by a once enslaved woman in the Caribbean, Prince recounts her strategies to survive and overcome the hardships through acts of resistance. Among those were the numerous times when she took control over her body, her space and her speech by talking back to her owners and colonisers, thus deconstructing stereotypes about the silenced and passive enslaved woman. The story of Prince and the transformation of her bodily pains into voice and text are embodiments of resistance. Although the physical body has been traumatised and dis-membered, the textual/discursive body always remains and in that sense, the African Caribbean woman voices a bodily speech; one that is re-membered and re-connected inside as well as outside of the body, "a textual body that attempts to supplant the physical one" (Francis-Brockert 114), a body which actually becomes a "source of restorative abundance" (Bennett and Dickerson 10).

Throughout Philip's Genealogy of Resistance, the black African female's utterances appear as reshaped so as to voice the continuous processes of renewal and survival through speech and self-assertion. In the same way, in her poetry collection She Tries Her Tongue, Her Silence Softly Breaks, the verses are intimately linked to the poem's display on the page through a sort of umbilical connection; the poetic voice produces and reproduces the symbols of female discursive empowerment through the synecdoche of the tongue:

When
$\begin{aligned} & \text { Abdication of word } \\ & \text { Ashes }\end{aligned}$
$\begin{array}{lr}\text {... Silence } & \\ \text { Song } & \text { word } \\ \text { Might } & \text { I... like }\end{array}$

... pure utterance.

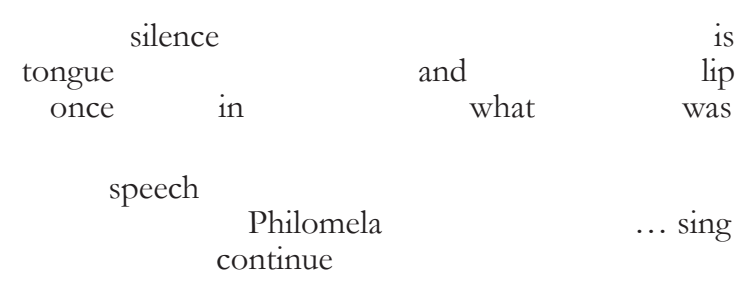

over

into

(Philip, She Tries Her Tongue 72)

The above passage suggests that the black female artist may find her own ways of expression through art as the reference to the Greek myth of Philomela implies. Philomela, who has endured a double rape (the rape of her body and the rape of her speech as her tongue was then cut and stolen), finds her only ways of expression in weaving and music. Despite this double mutilation, the female subaltern's "pure utterance" does resist as she finds expression through silence; thus silence can speak. In Philip's poetry, the act of silencing however symbolizes the rape of the expression of the self, a dual vision which is reminiscent of black feminist Hortense Spiller's definition of rape as the violation of both body and mind (68). The black female body has been historically 
mutilated on two important grounds, body and speech, and as a matter of fact, Philip's poetry condemns this subjugation; her poem "Mother's Recipes on How to Make a Language Yours or How Not to Get Raped" emphasises this association between physical body and discursive body. Memory thus allows speech and body to renew and heal.

The smallest cell

a sound

remembers

(sliding two semitones to return

home)

a secret order

among syllables

heart races

$$
\begin{aligned}
& \text { Leg/ba } \\
& \text { O/shun } \\
& \text { Shan/go }
\end{aligned}
$$

blood pounds

remembers

speech (37)

The dislocation of the verses on the page epitomizes the dangers of dis-membering. This means on the one hand, the fragmentation of the physical body, thus a dispersal of its members, and on the other, the forgetting of the sacred word, "the secret order/ among syllables" which must be uttered to allow self-assertion and self-representation, and above all to resist the silencing of the body.

In She Tries Her Tongue, the opening poem of her sequence entitled "Discourse on the Logic and Language," which ironically is rather illogical and discordant, the poetic voice seems silenced and alienated by the use of English, as the link between ("mother") and ("tongue") is explored:

I have no mother

tongue

no mother to tongue

no tongue to mother

to mother

tongue

me. (56)

The multi-functionality of word categories and the absence of punctuation in this excerpt illustrate Philip's wish to subvert and reconstruct language. While Philip's poems offer multiple interpretations to literary critics, their apparent lack of conformity often creates discord and confusion for modern Canadian readers, a strategy that is still prompted by a wish to deconstruct and reconstruct language. Philip's discourse is disorientating, as it is characterised by non-standard patterns, and the omnipresence of silences materialised by the gaps on the page, a style that attracts the reader's attention through the form, hence highlighting the contents. She seeks to trouble the reader's normative perceptions through a new disorientating language, a tongue of her own. This strategy is reminiscent of Indian Canadian writer Ashok Mathur's non-standard paper entitled DisOrientation Chapbooks where unheard voices were published in a chapbook format in order to displace the reader's perception through disturbing linguistic forms. Robert Budde draws a link in terms of objectives between NourbeSe Philip's work and these chapbooks and acknowledges "the form of the book as a site of resistance and 
ideological contestation. This type of art puts tremendous pressure on the connection between form (the shape, rhythms of discourse, signs, representations, etc.) and ideology (the systems of meaning fortified by those forms). Form undoes race" (293) and specific discursive strategies have transformative powers.

Philip's synecdoche of the tongue, which is central to the whole collection, reveals the poet's main preoccupation, as the tongue represents a vital part of the human body giving the power of speech and therefore the power of self-definition. The poem "Discourse on the Logic and Language" conveys a certain confusion and drives the poetic voice to a definite conclusion, that English cannot be her mother tongue. Hence the tongue must be reconstructed and reshaped so that the body may be able to express the reality of its specific experience. As Gender Studies theorist Patricia Mohammed explains, in the Caribbean and its diasporas, the linguistic situation is a complex one, as modes of communication do not only depend on English but on Creole language, on popular culture as well as on what she terms "the Creole expression of the body in Caribbean society, the language of intimacy" (21). This Creole expression of the body can be defined as a cultural bodily language that crosses gender, race and class boundaries, as it is a language whose codes are created and recreated within Caribbean local communities. Bodily language and sounds such as the African Caribbean kiss teeth, that prolonged sound of disapprobation, ${ }^{3}$ epitomize the complexity of diasporic African tongues. Philip's imagery of the tongue actually seeks to allow the African Caribbean woman to overcome her historical silencing by constructing her own coding. In Philip's poetry and prose, the conception of English as pure is disturbed, as the diasporic African woman is endowed with a language of her own construction; this is a language that she re-discovers and re-members in order to voice her specificities and reclaim her historically distorted body. Throughout Philip's texts, the reader is constantly confronted with a new language and silences are progressively transformed into bodies of speech, a language/silence dichotomy which is underlined throughout Pedro Carmona-Rodriguez's study Discourses of Dissent: Language, Silence and Transcultural Transit in Marlene NourbeSe Philip's Writings.

In fact, NourbeSe Philip's poetic deconstruction of the English language occurs through "the crack of silence," when the body speaks, when "the body becomes tongue":

That body should speak

When silence is,

Limbs dance

The grief sealed in memory;

That body might become tongue

Tempered to speech

And where the latter falters

Paper with words

The crack of silence. (72)

Here the poet further transforms the silent wounded bodies into linguistic testimonies where "the grief [is] sealed in memory" (Philip, She Tries Her Tongue 72), and the scribal appears to allow the healing of "this body whose flesh carries the female and the male

3. "Kiss-teeth is an everyday Caribbean oral gesture; it is an inherently evaluative and inexplicit oral gesture with a sound-symbolic component, and a remarkably stable set of functions across the diaspora: an interactional resource with multiple possibilities for sequential organization, often used to negotiate moral positioning among speakers and referents, and closely linked to community norms and expectations of conduct and attitude" (Figueroa and Patrick 1). 
to the frontiers of survival," as Hortense Spillers would formulate it (67). In Abeer Refky Seddeek's words, Philip's She Tries Her Tongue is “a clear protest against the gendered, racist and sexist silencing practiced by the colonisers against the colonised. In it, Philip strives to break the silence and to re-obtain the language that has been inhibited inside the African female slave" (305). Through Philip's poetry, the black female body claims its right to exist and survive as the poetic voice seeks to recreate the body beyond historical trauma and prejudice.

Grace Nichols's poetry collection The Fat Black Woman's Poems depicts the reconstruction of the black woman's I-mage through the deconstruction of historical stereotypes on the black woman in North America. Black feminist Patricia Hill Collins identifies four main representations of the black woman in North American societies: the mammy, the matriarch, the welfare mother, and the Jezebel (73). The most common myth is certainly the representation of the black woman as a docile and servile mammy, generally depicted as over-weight and dark-skinned. Barbadian historian Hilary Beckles extends the myth of the mammy to the Caribbean context and argues that black women were defeminised:

The black woman was ideologically constructed as essentially "non-feminine" in so far as primacy was placed upon her alleged muscular capabilities, physical strength, aggressive carriage, and sturdiness. Pro-slavery writers presented her as devoid of the feminine tenderness and graciousness in which the white woman was tightly wrapped. (10)

African Caribbean writers and theorists have struggled to deconstruct these racist representations of the black woman as anti-feminine, and as the passive and obedient fat dark-skinned mammy. Caribbean-American feminist Barbara Christian actually subverts the myth of the harmless domestic mammy in her analysis of slave narratives, as she describes a mammy who is a "cook, housekeeper, nurse-maid, seamstress, always nurturing and caring for her folk. But, unlike the white southern image of the mammy, she is cunning, prone to poisoning her master, and not at all content with her lot" (5). In her poetry collection, Grace Nichols also brutally deconstructs the "mammification" process (Collins 74) and subverts historical racial stereotypes.

In her poem entitled "Thoughts drifting through the fat black woman's head while having a full bubble bath," the fat black woman is depicted through her activist ideals which seem to intermingle with her body:

O how I long to place my foot

on the head of anthropology

to swing my breasts

in the face of history

to scrub my back

with the dogma of theology [...] (Nichols 13)

In this excerpt, the black female body seeks reconstruction through rebellion against canonical discourse and against major theoretical fields, whether it is anthropology, history, religion, medicine, aesthetics or linguistics. Nichols's poetry inverts the historical process of objectification and fragmentation of black female bodies, as she chooses to depict those dominant theoretical discourses as tightly associated with the biological parts of the black female body itself. This discursive framework which historically degraded and fragmented the black female flesh and psyche is now challenged by the 
poetic voice which attempts to deconstruct and reshape it, hence illustrating French Feminist Hélène Cixous's statement that

Woman must write her self: must write about women and bring women to writing, from which they have been driven away as violently as from their bodies - for the same reasons, by the same law, with the same fatal goal. Woman must put herself into the text - as into the world and into history - by her own movement. (875)

Defying the master codes, Nichols's poetic voice imprints her body parts on the page and the imagery of the fat black female reflecting while soaking in a bubble bath is a mixture of femininity and resistance. The black female subject is made highly visible throughout this poetry collection, which allows her to perform within the spaces previously denied to her. Through the re-empowered figure of the fat black woman who performs her poems beyond stereotypical assumptions, Grace Nichols's bodily poetics exemplifies diasporic African Caribbean women writers' urge for spatial repossession and bodily self-reclamation. As Andrea Elisabeth Shaw explains in The Embodiment of Disobedience: Fat Black Women's Unruly Political Bodies,

Superimposing fat onto the black female body doubles its representative status as the antithesis of white femininity, since the dominant perspective on fatness in Western culture replicates the view of what blackness is already understood as denoting: bodily indiscipline and rebellion. This assessment of fatness and blackness as highly sexualised concomitantly supports a Western patriarchal ideal of chastity and restraint as behavioral demonstrations of beauty. (50)

In her poem "The fat black woman remembers," Nichols's poetic voice goes further in her deconstruction of historical stereotypes such as Aunt Jemima or the black mammy, through a series of phrases conveying contradictory representations:

The fat black woman

remembers her Mama

and them days of playing

the Jovial Jemima [...]

Starching and cleaning (5)

The fat black woman remembers her imposed performance of the jovial domestic Jemima, reminiscent of the Aunt Jemima pancake boxes, and an extension of the figure of the black matriarch, the evil black mother.

[...] pressing little white heads against her big-aproned breasts seeing down to the smallest fed feeding her own on Satanic bread

But this fat black woman ain't no Jemima

Sure thing Honey/Yeah (5)

The final stanza depicts a scene which re-exploits the racist construction of the servile black mammy feeding white children with her "big-aproned breasts" while "feeding her own [children] on satanic bread." This image is reminiscent of Philip's representation of infanticides, but it also recalls Beryl Gilroy's analysis in "Swingers' Past and Present" which mentions enslaved women on plantations as "colloquially named 'Long Bubbies" (11), and as associated with bestiality. Where Philip is obsessed with the symbolism of the tongue, Nichols insists on the imagery of the breasts. During slavery, fecundity and breastfeeding were fundamental to enslavers who saw African women as 
"wombs of iron and gold" (Meillassoux 313). In her study, Andrea Shaw draws an analogy between Nichols's fat black woman and Nanny of the Maroons, the one-breasted female warrior whose "use of her fleshy buttocks in an act of rebellion places her as a viable entity in the discussion of the fat black woman's sexuality" (70-1). Nichols's fat black woman is therefore a female warrior figure who swings her breasts and buttocks at misrepresentations, hence rejecting the historical continuum of oppressions against women of African descent.

Grace Nichols's poetry allows the fat black woman to reject discriminatory discourses and assert her identity in a colloquial language of her own. At the end of the poem, the discursive construct of the assertion "But this fat black woman ain't no Jemima / Sure thing Honey / Yeah" appears to echo Sojourner Truth's rhetorical question “Ain't I a woman?" This last verse actually reminds the reader that this is performed poetry, and that the fat black woman's voice is constantly resonating throughout the poems. Nichols's poetry indeed grows more significant in performance, as the fat black woman's voice can be heard beyond the physicality of the body. In a sense, the discursive and physical bodies intermingle, to replicate Butler's theory of gender performativity ("Performative Acts" 155). Nichols's "fat black woman's body" is indeed in perpetual tension, it is "multiple" as opposed to "unitary":

The unitary subject is the one who knows already what it is, who enters the conversation the same way as it exits, who fails to put its own epistemological certainties at risk in the encounter with the other, and so stays in place, guards its place, and becomes an emblem for property and territory, refusing self-transformation. (Butler, Undoing Gender 28)

Far from being "unitary," Nichols's bodies are embodiments of self-transformation and disturbance. Similarly to Philip's poetry, Nichols's poetic strategy implies a certain subversion of canonical English by disturbing accepted grammatical categories and given constructs, so as to create new alternative spaces for bodily assertion through speech. The two poems "The Fat Black Woman Composes a Black Poem" (14) and "...And a Fat Poem" (16) function together so that they deconstruct binaries and reject normative categorisation. While the first is an obvious satire on stereotypical perceptions of blackness as associated with exoticism and sexuality (black and bold, black and sweet, black and beautiful, black music...), the second uses fatness within an anaphoric pattern and makes it a central feature in the following poem:

Fat is

as fat is

as fat is

Fat does

as fat thinks

Fat feels

as fat please

Fat believes [...]

and fat speaks for itself. (17)

Not limited to its primarily adjectival category, the word "fat" acts as a subject throughout the poem and is surely a personification of the fat black woman figure. Fatness is here positively associated with freedom of speech, belief, feeling and choice, hence allowing bodies to exist as such, without being restricted by Western norms of beauty. The fat black female body is not depicted as passive, it is not a commodification, it is now a liberated entity, one that can perform its own identity (triplication of "fat is") and construct 
its own speech against the master discourse ("fat speaks for itself"). "By creating a protagonist whose otherness is triply configured through her race, gender, and size, Nichols contests the marginalization of non-white and non-male individuals within a Caribbean postcolonial context" (Shaw 55).

The poem entitled "Afterword," which concludes the collection, depicts the fat black woman as transcending traumatic stereotypes and as eventually reconstructing her own subjectivity, one that embraces fatness, gender, race and class:

Behold now the fat black woman

who will come out of the forest

when the last of her race

is finally and utterly extinguished [...]

the fat black woman will emerge

and tremblingly fearlessly

stake her claim again. (16)

The fat black woman is here a personification of survival against all odds; beyond the traumatic erasure of her counterparts, she still "come(s) out of the forest," she still "emerge(s)," and her speech remains audible until the end of the poem. In the same way as Philip portrays a black female body which breaks the silence, Nichols allows the fat black woman to have the concluding words as she "fearlessly stakes her claim again" (16). Through the adverb "again" and the repetition of "last," the fat black woman's speech is depicted as forever recreating and renewing in a sort of discursive endlessness. In Nichols's poems, the black female body is forever resurrecting and reconstructing itself through speech and bodily performance, as "one is not simply a body, but, in some very key sense, one does one's body and, indeed, one does one's body differently from one's contemporaries and from one's embodied predecessors and successors as well" (Butler 524).

Grace Nichols's work is complex in its treatment of corporeality and her poetry is one of disturbance and deconstruction, in which body and voice are central and in constant tension with the outside hegemonic wor(l)d. In the same way as that of Philip, her poetry seems to work towards the ultimate goal of "decentring the language" which has contributed to fragmenting African bodies and selves (She Tries 88). Ultimately, both Nichols and Philip seek to represent the black female body/self against its historical misrepresentations as soundless and invisible, thus turning silence into productive utterance. Indeed, "women must write through their bodies, they must invent the impregnable language that will wreck partitions, classes, and rhetorics, regulations and codes, they must submerge, cut through, get beyond the ultimate reserve-discourse" (Cixous 886). Nichols's fat black woman rejects submissiveness and becomes the epitome of self-assertion, as in her poem "Assertion" she actually decides to "sit down on the golden stool of authority and refuses to move" (8). Nichols's fat black woman indeed chooses to empower herself through self-positioning and refusal to "censor her body," to quote Hélène Cixous further:

By writing her self, woman returns to the body which has been more than confiscated from her, which has been turned into the uncanny stranger on display - the ailing or dead figure, which so often turns out to be the nasty companion, the cause and location of inhibitions. Censor the body and you censor breath and speech at the same time. Write your self. Your body must be heard. (880) 
Through the re-membering and repositioning of their African ancestors' distorted bodies, Philip and Nichols actually negotiate new forms of subjectivity beyond bodily materiality; they subvert the master codes and deconstruct the master language in order to claim their own speech. For Philip, re-membering the body entails reclaiming and reshaping the tongue and voicing its trauma in order to heal. For Nichols, the body must be re-membered against its stereotypical representations and reconstructed through performance. Healing entails the re-assembling of the self through discursive performativity and through bodily re-envisioning. Both female poets truly engage in a similar process of "resistance that stretches beyond discursive realms" (Bennett and Dickerson 316), as they reclaim their flesh-and-blood bodies while re-membering their language. As a matter of fact, the task of the diasporic African Caribbean woman writer lies in the constant deconstruction of hegemonic and phallocentric discourses as her essential aim is to "revenge the self / broken / upon the word" (Philip, She Tries 56). Revenging the self thus supposes re-membering and reconnecting the fragmented selves through the power of discourse. Within this process of re-membering, recovery can be envisioned, and the diasporic Caribbean woman poet can engage in a genuine process of re-appropriation of her body and tongue. In a way, "this body - turned foreign, alien, and unfamiliar as the result of traumatic experience - becomes the vehicle through which trauma is told and, possibly, worked through" (Di Prete 4). The poetic texts of M. NourbeSe Philip and Grace Nichols function as writing, talking, and even performing cures, which allow self-healing and self-assertion through the creation of new therapeutic polyphonies that can be heard across borders.

Myriam MoÏsE

The University of the French Antilles

\section{Works Cited}

Beauvoir (de), Simone. The Second Sex. 1953. Trans. H.M. Parshley. Harmondsworth: Penguin, 1979.

BeCKLes, Hilary. Centering Woman: Gender Discourses in Caribbean Slave Society. Kingston: Ian Randle Publishers, 1999.

BennetT, Michael, and Vanessa Dickerson, eds. Recovering the Black. Female Body: Self-Representations by African American Women. New Jersey: Rutgers UP, 2001.

BudDE, Robert. "After Postcolonialism: Migrant Lines and the Politics of Form in Fred Wah, M. NourbeSe Philip and Roy Miki." Is Canada Postcolonial? Unsettling Canadian Literature. Ed. Laura Moss. Waterloo: Wilfrid Laurier UP, 2003. 282-94.

Butler, Judith. "Performative Acts and Gender Constitution: An Essay in Phenomenology and Feminist Theory." Theatre Journal 40.4 (Dec. 1988): 519-31.

—. Undoing Gender. New York: Routledge, 2004.

Carmona-Rodriguez, Pedro. Discourses of Dissent: Language, Silence and Transcultural Transit in Marlene NourbeSe Pbilip's Writings. Saarbrücken: Lambert Academic Publishing, 2011.

ChODORow, Nancy. The Reproduction of Mothering: Psychoanalysis and the Sociology of Gender. Los Angeles: University of California Press, 1978.

Christian, Barbara. Black Feminist Criticism, Perspectives on Black Women Writers. New York: Pergamon, 1985.

Cixous, Hélène. "The Laugh of the Medusa.” Signs 1.4 (Summer 1976): 875-93.

Coldins, Patricia H. Black. Feminist Thought: Knowledge, Consciousness and the Politics of Empowerment. New York: Routledge, 2002.

Conboy, Katie, Nadia Medina and Sarah Stanbury, eds. Writing on the Body: Female Embodiment and Feminist Theory. New York: Columbia UP, 1997.

Deleuze, Gilles. Foucault. Trans. Seán Hand. London: Continuum, 1988. 
Di PRete, Laura. Trauma, Corporeality and Textuality in Contemporary American Culture. New York: Routledge, 2006.

FigueroA, Esther, and Peter L. Patrick. "The Meaning of Kiss-Teeth." Essex Research Reports in Linguistics 35 (2001): 1-36.

Forbes, Curdella. "This Space/Dis/Place Between: The Poetics and Philosophy of Body, Voice and Silence." The Routledge Companion to Anglophone Caribbean Literature. Eds. M. Bucknor and A. Donnell. London: Routledge, 2011. 78-84.

Francis-Brockert, Allison. "That body should speak': How the Female Body Performs in The History of Mary Prince." Swinging Her Breasts at History: Language, Body and the Caribbean Woman's Text. Ed. Moira Inghilleri. London: Mango Publishing, 2006. 105-16.

Gilroy, Beryl A. "Swingers' Past and Present." Swinging Her Breasts at History: Language, Body and Caribbean Women's Texts. Ed. Moira Inghilleri. London: Mango Publishing, 2006. 2-15.

Grosz, Elizabeth. Volatile Bodies. Toward a Corporeal Feminism. Bloomington: Indiana UP, 1994.

Heller, Ben. "Landscape, Femininity and Caribbean Discourse". MLN 111.2 (1996): 391-416.

Mathur, Ashok. “The Desisting Reader.” West Coast Line 27.1 (Spring 1993): 67-73.

Meillassoux, Claude. The Anthropology of Slavery: The Womb of Iron and Gold. Trans. Alice Dasnois. Chicago: U of Chicago P, 1991.

Mohammed, Patricia. "Towards Indigenous Feminist Theorizing in the Caribbean." Feminist Review: Retbinking Caribbean Difference 59 (Summer 1998): 6-33.

New, W.H. Land Sliding: Imagining Space, Presence, and Power in Canadian Writing. Toronto: U of Toronto P, 1997.

Nichols, Grace. The Fat Black. Woman's Poems. London: Virago, 1984.

Philip, M. NourbeSe. A Genealogy of Resistance and Other Essays. Toronto: Mercury, 1997.

—. She Tries Her Tongue, Her Silence Softly Breaks. London: The Women's P, 1989.

PRINCE, Mary. The History of Mary Prince, a West Indian Slave. Related by Herself. London: F. Westley and A. H. Davis, 1831. http://docsouth.unc.edu/neh/prince/menu.html. Consulted 5 April 2012.

REFKY SEDDEEK, Abeer. "The African Female Body as a Form of Resistance in a Post-Colonialist Context: A Study of Marlene NourbeSe Philip's She Tries Her Tongue, Her Silence Softly Breaks." International Journal of Humanities and Social Science 4.7 (May 2014): 291-307.

SENFT, Theresa M. "Writing and Independence: Gayatri Spivak and the Dark Continent of Ecriture Feminine." Women and Performance 7.2.14-15 (Spring 1995): 275-86.

SHaw, Andrew Elizabeth. The Embodiment of Disobedience: Fat Black Women's Unruly Bodies. Lanham: Lexington Books, 2006.

Spillers, Hortense. "Mama’s Baby, Papa's Maybe: An American Grammar Book." Diacritics 17.2 (Summer 1987): 64-81.

SPIVAK, Gayatri Chakravorty. "In a Word. Interview with Eileen Roney.” Differences 1.2 (Summer 1989): 124-56.

Truth, Sojourner. “Ain't I a Woman?” The Norton Anthology of Literature by Women. Eds. S.M. Gilbert and S. Gubar. New York: W.W. Norton, 1985. 252-3.

Wainwright, Geoffrey, and Karen W. B. Tucker, eds. The Oxford History of Christian Worship. New York: Oxford UP, 2006.

Wollstonecraft, Mary. A Vindication of the Rights of Woman. New York: A.J. Matsell, 1833. http:// www.earlymoderntexts.com/assets/pdfs/wollstonecraft1792.pdf. Consulted 7 March 2017. 